Agro-Science Journal of Tropical Agriculture, Food, Environment and Extension Volume 12 Number 3 September 2013 pp. 9 - 14

ISSN II19-7455

\title{
RHEOLOGICAL PROPERTIES OF DANWAKE FLOUR BLENDS FROM SORGHUM, WHEAT AND CASSAVA BASES
}

\author{
Diarra, $M^{1}$, Nkama, $I^{2}$ and Hamaker, B. $\mathbf{R}^{\mathbf{3}}$. \\ ${ }^{1}$ Rural Economic Institute (IER), Food Technology Laboratory Sotuba, Bamako, Mali \\ ${ }^{2}$ Department of Food Science and Technology, University of Maiduguri, Maiduguri, Nigeria \\ ${ }^{3}$ Whistler Center for Carbohydrate Research, Department of Food Science, Purdue University, \\ West Lafayette Indiana Polis, USA
}

\begin{abstract}
The rheological properties of seven danwake flour blend formulations from sorghum, wheat and cassava bases were investigated. The different ingredients in the danwake were sorghum flour, cowpea flour, wheat flour, cassava flour, baobab leaf powder, and trona (sodium sesquicarbonate) (kanwa). The viscosity of the flour blends were determined using standard methods. The viscosity of the danwake flour blends decreased with the increase in shear rate, a case of pseudoplasticity. The viscosity also decreased with the increase in temperature for all of flour blends but increased with the increase in cowpea flour content in sorghum based danwake flour blends. The Power law indices obtained which were less than $1.00(n<1.00)$ confirmed the non- Newtonian and possibly pseudoplastic behavior of the pastes $(r=0.89-0.99)$. The Power law indices were significantly $(p<0.05)$ affected by the flour blend formulations and by temperature. The activation energies showed that pastes from sorghum based danwake with $7 \%$ cowpea and $30 \%$ cowpea gave the highest $(32.27 \mathrm{MJ} / \mathrm{mol})$ and the least (16.30 $\mathrm{MJ} / \mathrm{mol}$ ) sensitivity to temperature changes, respectively.
\end{abstract}

Key words: rheological, properties, danwake, sorghum and wheat.

\section{INTRODUCTION}

Increasing concern about the rising food cost combined with world food shortages, demand that closer attention be given to the usefulness of indigenous food sources as well as re-evaluation of the ways in which such foods are used (Jideani, 1990). 'Danwake' an indigenous, stiff dumpling food of the people in the northern part of Nigeria which is traced to be of the Nupe origin (Niger/Kogi State), is recommended to be considered in that process. Danwake is prepared from blends of sorghum/beans flours, wheat/ beans flours, and cassava/beans flours with the addition of baobab leaf powder and solutions of trona or 'kanwa' (Sodium sesquicarbonate). Data on the relationships between the physicochemical and rheological characteristics of danwake flour blends which contribute to the degree of fullness capacity of the dumplings when consumed is limited. Therefore, the objective of this study was to characterize the rheological behaviour of reconstituted danwake flour blends. The specific objectives were to determine:" the viscosity shear rate relationships and ii) the effects of flour blend formulations and temperatures on viscosity. The Power law and Arrhenius equations were used to describe the relationships between changes in shear rate, flour bend formulations and temperature.

\section{MATERIALS AND METHODS MATERIALS}

The materials used in danwake flour blend formulations are sorghum cultivar 'chakalari white', cowpea grain, wheat flour, cassava flour, baobab leaves powder, and trona (sodium sesquicarbonate) (kanwa) all purchased from Maiduguri Monday Market, Maiduguri, Nigeria. 


\section{METHODS \\ Preparation of samples}

The sorghum grain and cowpea grains were cleaned manually using screens and unwanted materials removed. The sorghum and cowpea grains were milled using a hammer mill (Gibbsons Electrical, Essex, UK) and sieved to pass through $500 \mu \mathrm{m}$ sieve.

\section{Formulation of Danwake Flour Blends}

Danwake flour blends from three bases, sorghum, wheat, and cassava flours were formulated with the addition of baobab leaf powder and trona (kanwa) as presented in Table 1.

\section{Preparation of Danwake Samples}

Danwake samples were produced by three different processors in Maiduguri Metropolis and also in the Department of Food Science and Technology Laboratory, following the procedure as described by Bamanga, 1992 and Alkali, 2004. $500 \mathrm{~g}$ of danwake flour blend formulations (Table 1) were mixed manually in plastic containers in $600 \mathrm{ml}$ of water to produce doughs. The doughs were moulded into small balls of about $20 \mathrm{~g}$ placed in boiling water in cooking pots and cooked for 15 to $30 \mathrm{~min}$ to doneness. During cooking, the balls were occasionally stirred using a perforated metal spatula to avoid sticking together of the balls. The cooked balls were placed in cold water then drained using a strainer. Samples for vitamin and mineral analyses were dried for $72 \mathrm{hr}$ in a solar dryer at a temperatures ranging from 38 to $56^{\circ} \mathrm{C}$. The dried samples were ground into powder using a manual kitchen grinder and stored at refrigeration temperature prior to analyses.

\section{Determination of the Rheological Property of damwake flour blends}

The cold and hot viscosities of danwake flour formulations were determined as follows. Slurries of danwake flour blends were prepared by dissolving $20 \mathrm{~g}$ flour in $200 \mathrm{ml}$ of distilled water to obtain a $10 \%(\mathrm{w} / \mathrm{v})$ concentration (Badau, 2005). The cold paste viscosity of danwake flour blends were determined using Brookfield Viscometer RV model (Brookfield Engineering Laboratories, Mass USA) with spindle Number 4 at 100, 50, 20 and 10 rev. /min for 5, 2.5, 1, $0.5 \mathrm{~min}$, respectively. Three readings were taken at $2 \mathrm{~min}$ intervals for each of the four reading times $(5,2.5,1,0.5 \mathrm{~min})$ and was repeated twice in each case (Gomez et al., 1997). The readings obtained were multiplied by appropriate conversion factors supplied by the manufacturers to get the viscosity in centipoise units. The slurries for the hot paste viscosities were prepared as described above, cooked in a water bath to obtain cooking temperatures of 90 , 70 and $50^{\circ} \mathrm{C}$ successively. The pastes were further cooked for additional 2 min on a grill mounted on a stove and samples thereafter cooled to room temperature $\left(37^{\circ} \mathrm{C}\right)$ while simultaneously determining the viscosities at 90,70 and $50^{\circ} \mathrm{C}$. Duplicate determination were made for the cold and hot paste viscosities.

\section{Theoretical analysis of data}

Data obtained were fitted to the Power law model which is often used to analyse viscosity shear rate of food materials (Lewis, 1987) as follows:

$\mu_{\text {app }}=K y^{\mathrm{n}-1}$

where $\mathrm{K}$ is the consistency index, $\mathrm{n}$ the Power law index, and $\mu_{\text {app }}$ the apparent viscosity and $\mathrm{y}$ is the shear rate. On linearization, the equation becomes

$\ln \mu_{\text {app }}=\ln \mathrm{K}+(\mathrm{n}-1) \ln y$

This implies that a plot of $\ln \mu_{\text {app }}$ against $\ln$ y gives a straight line of slope $(n-1)$ and intercept of $1 n$ $\mathrm{K}$, from which both the Power law and consistency indices can be obtained which are important in describing the rheological properties of food materials (Sopade and Kassum, 1992).

Also the temperature dependence of the consistency indices was determined using Arrhenius equation as follows:

$\mathrm{K}=\mathrm{K}_{\text {oexp }}\left(-\mathrm{E}_{\mathrm{o}} / \mathrm{RT}\right)$

Where $\mathrm{K}_{\mathrm{o}}$ is the consistency index at a reference temperature $(T-\alpha), E_{a}$ the activation energy (MJ $\mathrm{mol}^{-1}$ ), R the universal gas constant, and $\mathrm{T}$ is the absolute temperature. On linearization

$\ln \mathrm{K}=\ln \mathrm{K}_{\mathrm{o}}-\left(\mathrm{E}_{\mathrm{o}} / \mathrm{R}\right)(1 / \mathrm{T})$

when $\ln K$ is plotted against (1/T) a straight line of slope $(\mathrm{Ea} / \mathrm{T})$ is obtained from which the activation and sensitivity of the consistency index to temperature can be derived.

\section{Statistical Analysis}

The statistical analysis was carried out using the Statistics Package for Social Sciences (SPSS) version 16. All the values expressed in percentage were obtained using the frequencies under the descriptive statistics. The means, their standard deviations, and differences significance, were computed through the independent samples T-test. The significance of the assessment was set at 5.00 $\%$.

\section{RESULTS AND DISCUSSION}

The viscosities of the gruels from the seven danwake flour blends $(10 \% \mathrm{w} / \mathrm{v})$ are given in Figures 1 and 2, which are plots of viscosity in Ns $/ \mathrm{m}^{2}$ against shear rate (rps). The viscosity of the 
danwake flour blends decreased with the increase in shear rate, a case of pseudoplasticity (Lewis, 1987). The viscosity also decreased with the increase in temperature for all of the flour blends from the seven formulations. However, the viscosity increased with the increase of cowpea content in sorghum danwake. The major importance of the rheological behavior studies is in their significance in processing, quality control, sensory properties and structural investigations (Muller, 1973; Lewis, 1987; Badau, 2005).

The consistency index (K), the Power law index (n) and activation energy data from the analysis are shown in Table 1. The correlation coefficients of data (Table 1) ranged from 0.89 -

(a)
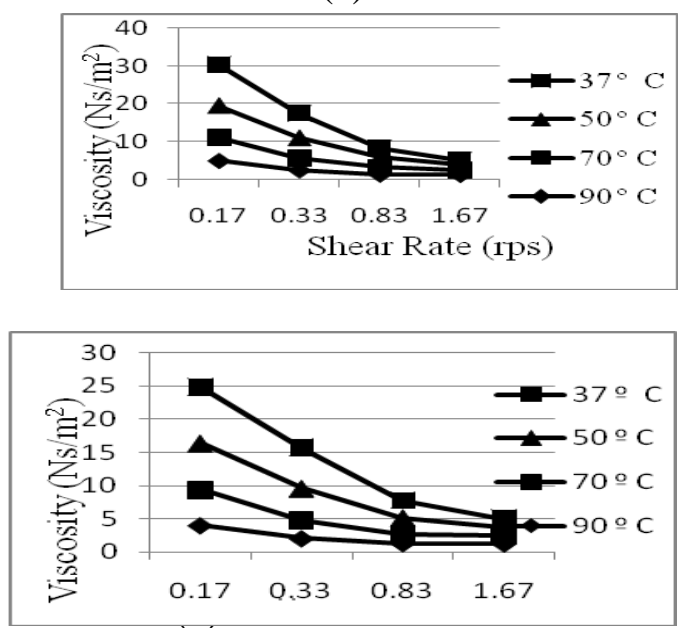

(c)

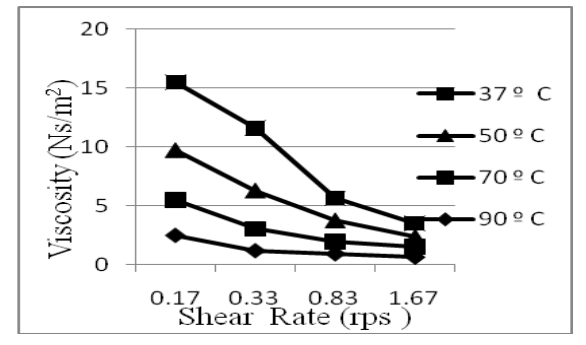

(e)
0.99 showing that the Power law equation adequately described the viscosity - shear characteristic properties of the danwake flour blend formulations. The Power law indices (n) were less than one, confirming the non Newtonian and possibly pseudoplastic behaviour of danwake flour blends (Finney, 1973). The $n$ values were significantly different $(p<0.05)$ for all danwake flour formulations.

The Power law indices were affected by changes in temperature contrary to other reports (Badau, 2006). The variation of $\mathrm{n}$ at different temperatures may be related to the physicochemical properties of the damwake flour blends.

(b)
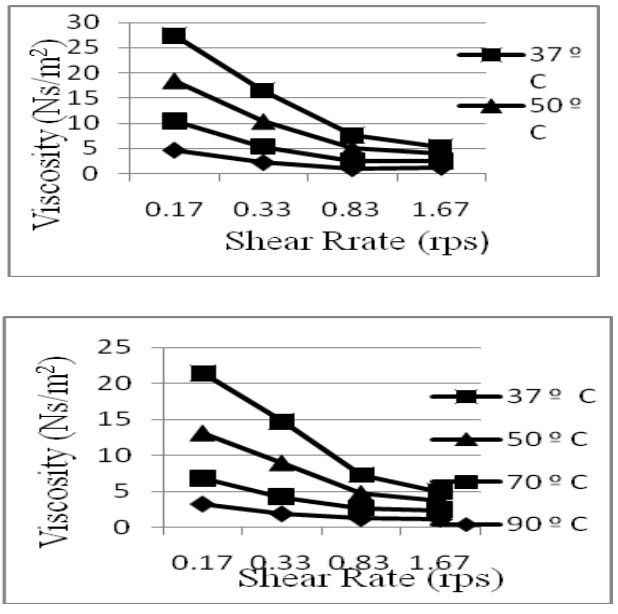

(d)

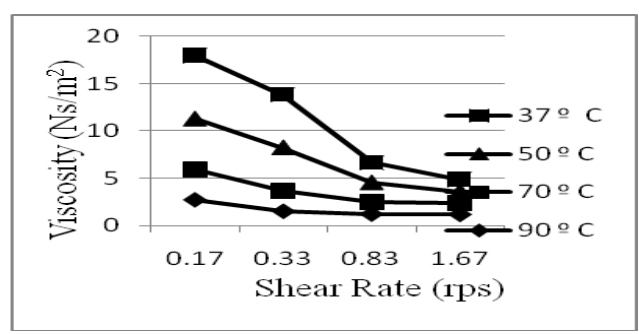

(f)

Figure 1: Plot of viscosity against shear rate of danwake flours, $10 \%$

concentration (w/v) at different temperatures: (a) sorghum (30\% cowpea), (b) wheat (0\% cowpea), (c) cassava (11 $\%$ cowpea), (d) sorghum (16\% cowpea), (e) sorghum (11\% cowpea), and (f) sorghum (7\% cowpea) 
Table 1: Formulations of Sorghum, Wheat and Cassava Danwake Flour Blends (g ingredients $/ 100 \mathrm{~g}$ of flour blend)

\begin{tabular}{|c|c|c|c|c|c|c|c|}
\hline \multirow[t]{2}{*}{ Ingredients } & \multicolumn{7}{|c|}{ Formulations } \\
\hline & 1 & 2 & 3 & 4 & 5 & 6 & 7 \\
\hline Sorghum & 67.75 & - & - & 76.69 & 79.92 & 89.33 & 90.39 \\
\hline Cowpea & 30.00 & - & - & 16.26 & 11.34 & 7.12 & 5.06 \\
\hline Kuka & 1.50 & - & - & 3.63 & 4.53 & 1.47 & 1.80 \\
\hline Potash & 1.75 & - & - & 4.03 & 4.20 & 2.09 & 2.74 \\
\hline Wheat & - & 95.88 & - & - & - & - & - \\
\hline Cowpea & - & 0.00 & - & - & - & - & - \\
\hline Kuka & - & 2.90 & - & - & - & - & - \\
\hline Potash & - & 1.22 & - & - & - & - & - \\
\hline Cassava & - & - & 79.92 & - & - & - & - \\
\hline Cowpea & - & - & 11.34 & - & - & - & - \\
\hline Kuka & - & - & 4.53 & - & - & - & - \\
\hline Potash & - & - & 4.20 & - & - & - & - \\
\hline
\end{tabular}

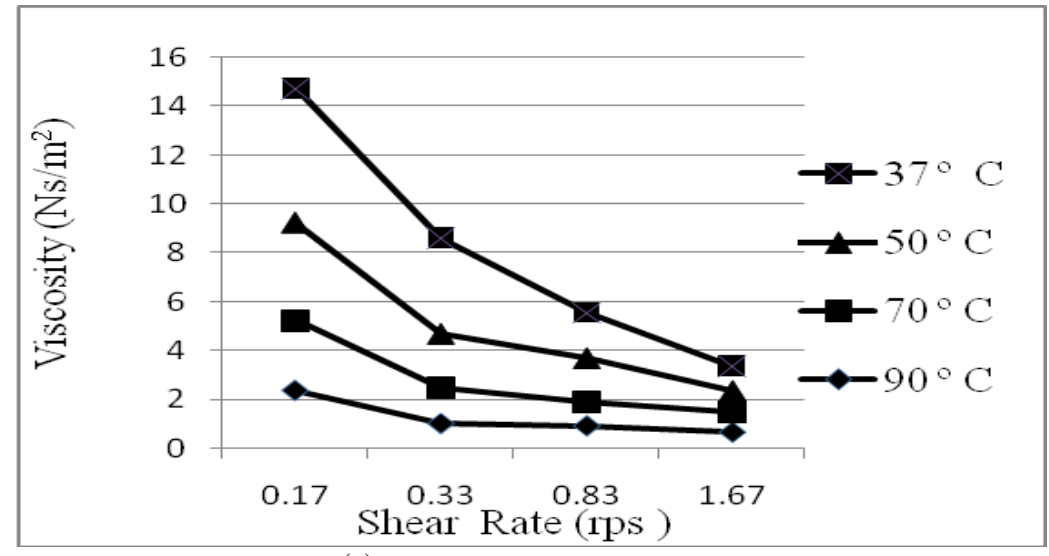

(g)

Figure 2: Plot of viscosity against shear rate of danwake flour, $10 \%$

concentration $(\mathrm{w} / \mathrm{v})$ at different temperatures: $(\mathrm{g})$ sorghum $(5 \%$ cowpea $)$

The activation energies (MJ/mol) of various formulations are shown in Table 1. It ranged from 16.30 for sorghum danwake containing $30 \%$ cowpea flour to 32.27 for sorghum danwake containing $7 \%$ cowpea flour. The danwake containing $30 \%$ cowpea flour showed least sensitivity to temperature changes. The curves from which these were calculated are shown in Figures 3.
It can be concluded from the foregoing that damwake flour blends when reconstituted in water exhibited a non - Newtonian behavior and was therefore pseudoplastic. Attempts at industrial processing of danwake flour blends must take this into consideration. In conclusion, the Power law and Arrhenius equations were adequately used to describe the relationships between changes in shear rate, flour bend formulations and temperature. 
Table 2: The Effects of Temperature and Formulations on the Power Law and Consistency Index Values of Sorghum, Wheat and Cassava Flour Blends for Danwake Production

\begin{tabular}{|c|c|c|c|c|}
\hline Temperature $\left({ }^{\circ} \mathrm{K}\right)$ & $\begin{array}{c}\text { Consistency Index } \\
(\mathrm{K})\end{array}$ & $\begin{array}{l}\text { Power Law Index } \\
(\mathrm{n})\end{array}$ & $\begin{array}{c}\text { Activation Energy } \\
(\mathrm{MJ} / \mathrm{mol})\end{array}$ & Correlation Coefficient (r) \\
\hline \multicolumn{5}{|c|}{ Sorghum danwake (30\% cowpea) } \\
\hline 310 & 0.77 & 0.06 & 16.30 & 0.99 \\
\hline 323 & 0.73 & 0.18 & & 0.99 \\
\hline 343 & 0.56 & 0.34 & & 0.99 \\
\hline 363 & 0.32 & 0.39 & & 0.95 \\
\hline \multicolumn{5}{|c|}{ Wheat danwake ( $0 \%$ cowpea) } \\
\hline 310 & 0.42 & 0.13 & 21.13 & 0.99 \\
\hline 323 & 0.27 & 0.21 & & 0.99 \\
\hline 343 & 0.05 & 0.32 & & 0.98 \\
\hline 363 & 0.26 & 0.26 & & 0.89 \\
\hline \multicolumn{5}{|c|}{ Cassava danwake (11\% cowpea) } \\
\hline 310 & 0.74 & 0.15 & 19.55 & 0.99 \\
\hline 323 & 0.69 & 0.26 & & 0.99 \\
\hline 343 & 0.43 & 0.37 & & 0.95 \\
\hline 363 & 0.29 & 0.48 & & 0.94 \\
\hline \multicolumn{5}{|c|}{ Sorghum danwake (16\% cowpea) } \\
\hline 310 & 0.73 & 0.17 & 20.88 & 0.99 \\
\hline 323 & 0.63 & 0.27 & & 0.99 \\
\hline 343 & 0.38 & 0.54 & & 0.98 \\
\hline 363 & 0.27 & 0.55 & & 0.95 \\
\hline \multicolumn{5}{|c|}{ Sorghum danwake (11\% cowpea) } \\
\hline 310 & 0.65 & 0.22 & 24.29 & 0.98 \\
\hline 323 & 0.60 & 0.32 & & 0.98 \\
\hline 343 & 0.31 & 0.56 & & 0.97 \\
\hline 363 & 0.21 & 0.55 & & 0.95 \\
\hline \multicolumn{5}{|c|}{ Sorghum danwake ( $7 \%$ cowpea) } \\
\hline 310 & 0.53 & 0.21 & 32.27 & 0.97 \\
\hline 323 & 0.34 & 0.33 & & 0.98 \\
\hline 343 & 0.05 & 0.45 & & 0.98 \\
\hline 363 & -0.20 & 0.46 & & 0.96 \\
\hline \multicolumn{5}{|c|}{ Sorghum danwake (5 \% cowpea) } \\
\hline 310 & 0.42 & 0.23 & 22.71 & 0.99 \\
\hline 323 & 0.27 & 0.39 & & 0.97 \\
\hline 343 & 0.05 & 0.45 & & 0.98 \\
\hline 363 & -0.25 & 0.49 & & 0.92 \\
\hline
\end{tabular}

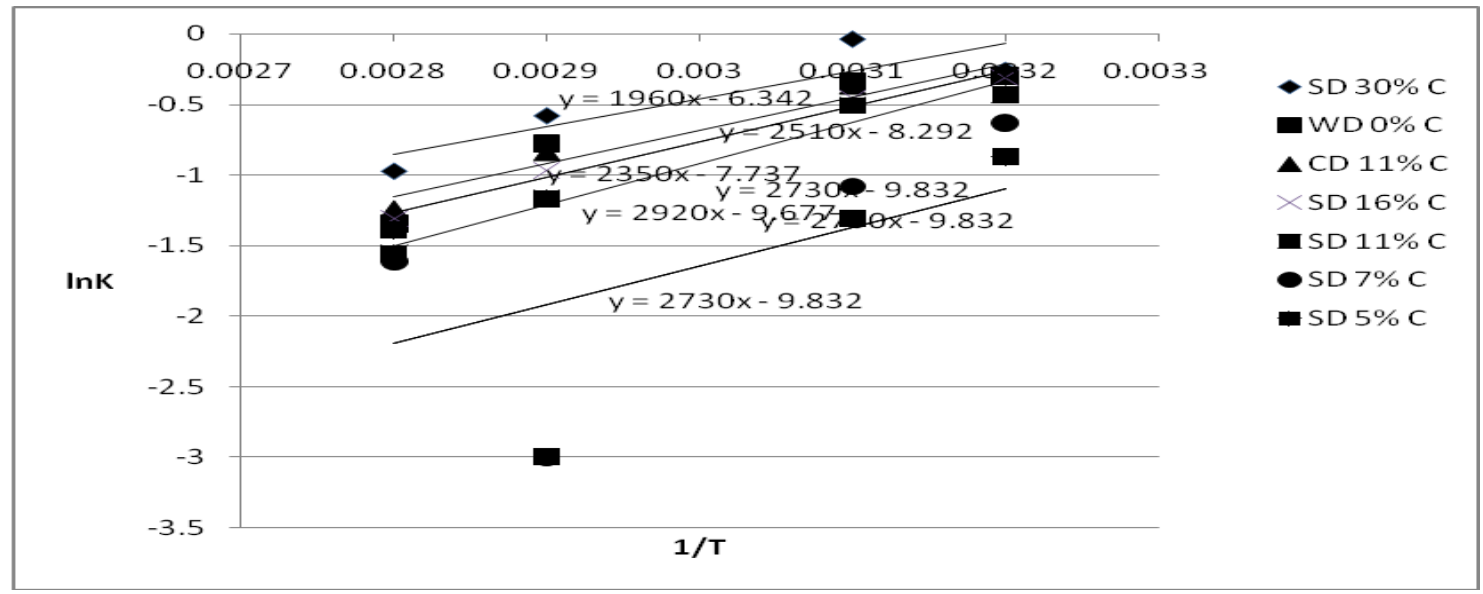

Figure 3: Temperature dependence of consistency index of danwake flour blends: SD 30\% C (sorghum danwake $30 \%$ cowpea), WD $0 \% \mathrm{C}$ (wheat danwake $0 \%$ cowpea), CD 11\% C (cassava danwake 11\% cowpea), SD16\% C (sorghum danwake $16 \%$ cowpea), SD $11 \% \mathrm{C}$ (sorghum danwake $11 \%$ cowpea), SD 7\% C (sorghum danwake 7\% cowpea) and SD 5\% C (sorghum danwake 5\% cowpea) 


\section{ACKNOLEGMENT}

The research team is grateful to the International Sorghum and Millet Collaborative Research Support Program (INTSORMIL- CRP) for funding the $\mathrm{Ph} . \mathrm{D}$. program under which the activities leading to this publication have been conducted.

\section{REFERENCES}

Badau, M. H. (2005). Physical, chemical, and malting characteristics of pearl millet cultivars and their food applications. Ph.D.Thesis, Abubacar Tafawa Balewa Univ., Bauchi,Nigeria.

Gomez, M. I., Obliana, A. B., Martin, D. F., Madzavamuse, M. and Monyo, E. S.
(1997). Manual of Laboratory Procedures for Quality Evaluation of Sorghum and Pearl millet.Technical Manual $\mathrm{N}_{\mathrm{o}} .2$ ICRISAT, Patencheru 502, 324. Andhra Pradesh, India.

Jideani, I. A. (1990). Acha-Digitaria exilis: The Neglected Cereal. Agric. Inter. 42: 5.

Lewis, M. J. (1987). Physical Properties of Food and Food Processing Systems. Ellis Horwood Ltd, Chiches

Muller, H. G. (1973). An Introduction to Food Rheology. Crane, Russak and Company, Inc., New York. 